\title{
Mitigating Climate Change via Non-Conventional Renewable Energy: Case of Sri Lanka
}

\author{
A. S. Withanaarachchi, L. D. J. F. Nanayakkara, and C. Pushpakumara
}

\begin{abstract}
In 1995 Sri Lanka produced $95 \%$ of the grid electrical energy needs from conventional hydro power plants. But today Sri Lanka's electricity generation sector is largely dominated by fossil fuel sources. Though the Sri Lanka's current carbon foot print is much less than the global average, rising energy demand has resulted in escalated greenhouse gas (GHG) emissions. The focus of this study is primarily on Non-Conventional Renewable Energy sector and the challenges that need to be overcome for a clean and sustainable energy future. The study took the form of three phases: primary data-gathering process through literature review, semi-structured interviews, followed by an expert panel discussion. Results show that, as small hydro power potentials have already been utilized, wind has come to the forefront as the most promising energy source. However, technical and infrastructural limitations have hindered the further development of not only wind, but also biomass and solar energy sources.
\end{abstract}

Index Terms - Climate change, renewable energy, Sri Lanka.

\section{INTRODUCTION}

The United Nations Framework Convention on Climate Change (UNFCCC) defines climate change as "a change of climate which is attributed directly or indirectly to human activity that alters the composition of the global atmosphere and which is in addition to natural climate variability observed over comparable time periods" [1]. The impacts of electricity generation on the environment could be due to one or several factors including: particulate emissions; Greenhouse gaseous emissions (GHGs); warm water discharges into lakes; rivers or sea; liquid and solid waste and changes of land use. Although many of these are common to any development project, particulate and gaseous emissions are of primary importance in the case of electricity generation using fossil fuels.

Access to energy has an important impact on long-term poverty reduction in developing countries [2]. By now energy mix of many developing nations and countries in transition, has been largely dominated by fossil fuels. Today overdependence on fossil fuels has forced the world to consider global warming and climate change via GHGs a critical issue which needs to be addressed immediately.

In 1995 Sri Lanka produced 95\% of its grid electrical energy needs from conventional hydro power plants. However, expansion of household electricity consumption

Manuscript received March 16, 2014; revised July 23, 2014.

The authors are with the Department of Industrial Management, University of Kelaniya, Sri Lanka (e-mail: amila.green@gmail.com, julian@kln.ac.lk, chamli@kln.ac.lk). and the boost in the industrial sector of the country have forced the country to depend on alternative energy resources such as fossil fuels. The total amount of electricity generated during 2012 was $11,878.8 \mathrm{GWh}$ out of which $70.9 \%$ was from thermal power plants (both oil and coal), while $23.0 \%$ was from major hydro and the balance $6.2 \%$ was from Non-Conventional Renewable Energy (NCRE) which comprised of small hydro, wind power, biomass and solar [3].

\section{RESEARCH OBJECTIVES}

Considering the fact that Sri Lanka's largest reserves of hydro power have already been utilized, the Ceylon Electricity Board (CEB) of Sri Lanka had diversified to thermal power, resulting in a gradual shift in the industry power mix [4]. Based on World Bank reports, the following table (Table I) exhibits the per capita carbon dioxide emissions of different regions compared with Sri Lanka.

The per capita carbon dioxide emission in Sri Lanka at present is only 0.6 metric tons per year, which is far below the global average of 4.9. This indicates that Sri Lanka has adequate carbon space for establishing fossil fuel power plants [5]. As evidence by many international publications, the unprecedented levels of economic growth emerging in the developing nations will make them responsible for future growth in energy demand [6]. In catering to the rapid demand growth, current electricity generation expansion plan of Sri Lanka is mainly concentrated on imported coal.

TABLE I: AVERAGE $\mathrm{CO}_{2}$ EMISSION METRIC TONS PER CAPITA IN YEAR 2010

\begin{tabular}{cc}
\hline \hline Country/ Region & 2010 CO2 Emissions (MT/capita) \\
\hline World & 4.9 \\
Low middle income countries & 1.6 \\
South Asia & 1.4 \\
Sri Lanka & 0.6 \\
\hline \hline
\end{tabular}

Coal has been identified as the least cost option taking into consideration mainly the cost of production [7]. Based on the published data, energy sector is the main contributor to the GHGs emission [8]. Thus clean energy is an essential requirement in combating the climate change.

The focus of this study is primarily on NCRE based electricity generation of Sri Lanka and the challenges that need to overcome for a clean and sustainable energy future Further this study is aimed at identifying and investigating factors, which influence the development of the NCRE sector of Sri Lanka. These factors were derived as an outcome of a workshop which was conducted with the experts in the renewable energy sector of Sri Lanka 


\section{Methodology}

To effectively address the research questions and objectives, a qualitative, exploratory and descriptive research design presented the most viable approach. Thus in this study, the research process was approached in three phases:

1) Phase one: Literature related to the government publications, policy papers and local academic publications were studied to explore the present energy situation of the country. International energy reports and international academic journals were studied to explore the potentiality of renewable energy sector and to ascertain the international developments in the clean-energy sector.

2) Phase two: Experts including government officials, academics and private investors pertaining to Sri Lankan renewable energy sector were interviewed to gain an insight into the challengers that the country needs to overcome in fostering the clean energy practices in the country.

3) Phase three: This study is further strengthened with the outcome of a workshop which the authors conducted with the experts representing the multiple disciplines. Due to the multi-discipline nature of the research question, policy makers, environmentalist, economists and sociologist also took part in the panel discussion together with the energy experts.

Majority of the previous studies pertaining to the Sri Lankan clean-energy sector are confined to technical documents which do not discuss the real socio-economic implications behind the core issue. Thus this study is different to the similar studies in Sri Lanka as this is an overview of social, technological, economic, environmental and political factors behind the core issue with respect to the renewable energy sector of Sri Lanka.

\section{RENEWABle ENERGy SeCtor AND CHALlENGES}

\section{A. Rising Electricity Demand}

Reaping the benefits of the peace dividend, the country's economy has been showing robust growth, in turn accelerating the demand for power. The current statistics show that the country's electricity demand has been growing at an average rate of $5.9 \%$ per annum [9]. Fig. 1 exhibits the gross electricity usage from year 2000 to year 2012.

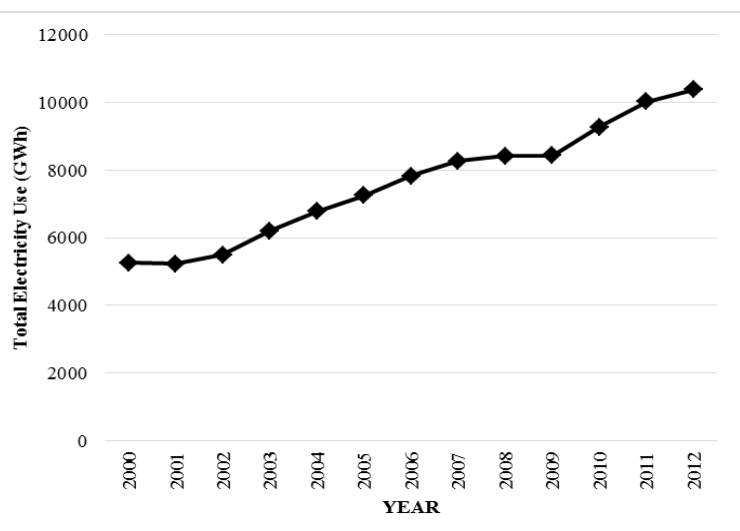

Fig. 1. Electricity demand in Sri Lanka (GWh) [3].
Experts claim that, with the current escalating demand, the demand for electricity will be doubled by 2020 compared with the 2010 figure. More specifically, the in year 2010 the base load of the country was 9,268 GWh and CEB Long term generation expansion plan forecast the demand to reach $16,937 \mathrm{GWh}$ by year 2020 [10].

\section{B. Electricity Generation Power Mix}

Table II exhibits the gross generation to the grid from different energy sources for the past few years. These statistics show that it is the thermal oil which is the highest contributor for the nation's electricity generation, followed by major hydro.

NCRE contribution has been increasing gradually over the past few years. The decline of the contribution of NCRE in 2011 can be attributed to the introduction of the $300 \mathrm{MW}$ coal power plant in that year.

\section{Non-Conventional Renewable Energy Sector}

If we take the NCRE alone, mini hydro is the highest contributor to the renewable energy sector followed by wind and biomass. The presence of solar based energy in the national grid supply was minimal by year 2011. The dependency on mini hydro sector has driven the NCRE based electricity generation to depend on the rain fall, which in turn encourages the thermal sources to be used in dry seasons.

TABLE II: Gross Generation to GRID AS A PERCENTAGE (\%) TO TOTAL PRODUCTION [10]

\begin{tabular}{llllllll}
\hline \hline Power mix & 2005 & 2006 & 2007 & 2008 & 2009 & 2010 & 2011 \\
\hline Major Hydro & 36.4 & 45.4 & 36.6 & 37.0 & 33.7 & 46.2 & 34.6 \\
Thermal Oil & 60.4 & 50.9 & 59.9 & 58.6 & 60.8 & 47.0 & 50.4 \\
Thermal Coal & - & - & - & - & - & - & 8.8 \\
NCRE & 3.2 & 3.7 & 3.5 & 4.4 & 5.5 & 6.8 & 6.2 \\
\hline \hline
\end{tabular}

\section{Small Hydro}

Hydropower plants rated below $10 \mathrm{MW}$ are referred to as small hydro plants [8]. As of 31st October 2012, 217MW of mini hydro plants have been connected to the grid while another 153MW have been earmarked [10]. Small hydro took the lead in NCRE power sector due to several reasons. Technologies required to harness hydro resource potential are well developed and are available from many sources, including local manufactures. Apart from turbines and other electro-mechanical devices, water conveyance structures and diversion structures too exhibit considerable level of maturity in Sri Lanka [11]. Secondly, relatively low capital requirement and attractive tariff structures are the main driving forces for the sector's development.

Hydro resources are mainly dominated by the two monsoons, thus electricity generation via small hydro power plants are highly vulnerable to weather conditions. On the other, hand most of the small hydro power potential has already been utilized for electricity generation and the balance undeveloped potential sites are in forest areas and difficult terrains. Thus more than the land required to build the plant, building of a transmission line of many kilometers to take power to the closest substation would involve clearing of forest land causing much damage to the environment [8].

The existing hydro power plants with regulating reservoirs are not sufficient to meet the peak demand. Hence authorities 
are currently considering the possibility of operating a pump storage hydropower plant to meet the electricity demand during the peak hours. Studies conducted by "Sri Lanka Energy Management Association" indicate that there are many sites suitable for consideration for development of pump storage power plants [12]. The Ministry of Power \& Energy has already started discussions with the South Korean government to transfer the knowhow on pump storage to Sri Lanka. This is a new power generation concept to Sri Lanka. Thus studies are underway to analyze the economic and technical feasibility of this concept.

\section{E. Wind Power}

Globally, harnessing wind energy for electricity generation is one of the fastest growing technologies for the last decade or so and has become well developed and mature [13]. The wind-mapping studies performed by the US National Renewable Energy Laboratory (NREL) found that Sri Lanka has many areas estimated to have good-to-excellent wind resources, with wind power densities in the range $200-600$ $\mathrm{W} / \mathrm{m} 2$ in the north-western and south-eastern coastal regions and in north-central region, and exceeding $600 \mathrm{~W} / \mathrm{m} 2$ in the central highlands. The study has further revealed that as much as 2000 MW of wind power could be absorbed gradually into the national grid over the period of time [8]. In other parts of the world, where the wind potential is relatively high, the cost of wind electricity is shown to be very competitive to that of conventional fossil fuels. In particular, large scale wind energy developments result in considerable reduction of project costs. However, in Sri Lanka, due to the relatively smaller scale of wind projects allowed for development (i.e. less than 10MW), the cost of imported technologies remain prohibitively expensive. Thus, the unit cost of wind derived electricity remains considerably higher than average selling price of electricity [11].

In Sri Lanka, a pilot scale wind power plant of $3 \mathrm{MW}$ capacities consisting of 5 wind turbines of $600 \mathrm{~kW}$ each was commissioned in 1999. By the end of October 2012, the private sector has developed wind power plants around costal and central hill areas adding $74 \mathrm{MW}$ to the national grid. Further, power purchase agreements have been signed for another $31 \mathrm{MW}$ [10]. In order to capture the benefits associated with large scale wind farms, initiatives have been taken to establish wind-parks in high potential areas in the future. Further, efforts are underway to increase the local value addition in wind energy conversion, in an attempt to bring the cost of wind electricity below the average selling price.

Wind energy conversion systems require wider and less winding roads for transport. Hence, the central highlands are mostly unavailable for large turbine based wind projects, which require transportation of long and heavy turbine components in heavy vehicles. Further technical issues in the national grid and the unstable nature of wind resource have cause limitations in absorbing wind powered electricity to the national grid.

\section{F. Biomass Based Electricity Generation}

Biomass accounts for over $10 \%$ of global primary energy supply and is the world's fourth largest source of energy (following oil, coal, and natural gas) [14]. The bioenergy sector is relatively complex because there are many forms of biomass resources; various solid, liquid, and gaseous bioenergy carriers; and numerous routes available for their conversion to useful energy services [14].

At present, $46.4 \%$ share of the total primary energy supply of the country is met with biomass. Large quantities of firewood and other biomass resources are used for cooking in rural households and to a lesser extent, in urban households. Considerable portion of biomass also been used in the industry primary to generate heat. Most of such biomass is in the form of firewood, bagasse and charcoal. Bagasse is the waste form of sugar cane, which is used in sugar factories for combined heat and power generation. By 2012, only a single sugar factory was reported to be in operation and it used bagasse for power generation to meet their in-house power requirements. Charcoal is produced mainly from coconut shell and wood. A major portion of the coconut shell charcoal production is exported as a non-energy product [3].

In the Sri Lankan context fuel wood and agricultural residues are the most common form of biomass available for electricity generation. In recent times biomass has attracted interest as a primary energy source for electricity generation due to its potential as at low cost, indigenous supply of energy with considerable environmental benefits such as reduced carbon dioxide emissions, reduced soil erosion and restoration of degraded lands. Other advantages include social benefits, such as creation of local employment and improved availability of fuel wood for household use [15].

Maintaining a regular supply of biomass to fuel the plant is the main challenge for effective implementation of commercial scale biomass plants. Though the current tariff system offer an attractive price for biomass, technical, practical and business realities have led the biomass to lag behind other renewable options. Unlike hydro, wind and solar, where the resource naturally flow, biomass investors have to grow, manage, harvest, chop, dry and feed it into the power plant. This is vulnerable to weather conditions as well. Thus by 31 st October 2012 , only a $0.5 \mathrm{MW}$ biomass power plant which uses fuel woods was in operation. Convenient biomass which uses agricultural residues are the only biomass solution that operate effectively in Sri Lanka. As at the above date, there were $11 \mathrm{MW}$ of such plants in operations [10].

\section{G. Solar Power}

In a global context, grid connected solar PV is the fastest growing energy technology with an annual average growth rate of $60 \%$ during the five year period from 2005 to 2010 [11]. Solar PV cell converts sunlight directly into electricity and is a well-established technology particularly for sites that are far from the distribution network [10]. Thus as in many other developing countries, in Sri Lanka, solar home systems have been used by the rural communities away from the national grid to provide essentials such as lighting and operation of a radio and black and white television [8]. But due to the fast expansion of the national grid, standalone solar home systems in rural villages are losing popularity. Yet, the use of solar energy as a supplementary source of electricity generation in commercial buildings and industrial facilities is gaining momentum with the promotional instruments such as 
green buildings and also through net metering facility [11].

Technical limitations in the national grid and high initial investments are the main hindrances for the sector's development [10]. Thus as of 31st October 2012, grid connected capacity of solar power projects was mere $1.4 \mathrm{MW}$.

\section{H. Off-Grid Energy Sector of Sri Lanka}

In early 1990 's, since close to $75 \%$ of the people were living without electricity, the NGOs and private sector firms introduced stand-alone renewable energy technologies such as solar home systems and community based village micro-hydro power to cater to the electricity needs of the off-grid communities [16].

By year 2012, approximately 93\% of the total population had access to electricity from the national electricity grid [10]. Western province and Southern province have a level of more than $97 \%$ electrification in all districts. The Government has plans to continue extending the national grid, to cover 96-97\% of the population. Electrification of rural areas, poses many challenges, foremost amongst which are the high capital investment, operational costs and the difficulties associated with extending grid connected electricity lines to remote areas [17]. Hence, it is proposed to provide electricity to this balance $3-4 \%$ of the population from standalone off-grid technologies to achieve $100 \%$ electrification.

Among number of Off-grid power options technologies such as solar home systems, micro hydro power solutions, village Dendro power, wind home systems, village biogas power and pico hydro power are the options popular in Sri Lanka. According to present statistics solar and wind home power systems are commonly used for off-grid electrification. The wind is however seasonal and site specific. Therefore, wind energy technologies cannot be used in isolation for off-grid use and it needs to be used as a hybrid system. Wind-biogas and wind-solar hybrid systems were pilot tested during the past however, those proved to be costly and unaffordable to off-grid communities [16]. Thus recent studies reveal that among the two options (wind and/or solar) solar home systems are quite popular in the country [18].

\section{Future of NCRE Power Generation}

The overall favourable economic prospects, increased investments in the industrial and manufacturing sectors, coupled with the government's long-term vision of electrifying all households is expected to see uplift the demand for electricity. According to the CEB's long-term generation plans, thermal power is expected to spearhead the country's energy generation. For example by the year 2017, 2025 and 2032 thermal plants will supply 65\%, 75\% and $80 \%$ of the energy demand respectively [10]. While coal stands a cheaper alternative to oil, relying on coal would still be an expensive option for the country.

The present thermal capacity consists of petroleum fuel based plants and coal plant. New thermal capacity to be added to the system by 2032 is in the form of diesel plants, gas turbines and coal plants. Given the fact that Sri Lanka does not have its own fossil resources, and considering the anticipated increase in demand for fossil sources, specifically from developing countries and resultant price increases, relying on stated energy mix would still be an expensive option for the country.

In order to curb rising dependency on fossil fuels the government of Sri Lanka has taken an impressive policy decision to lift the renewable energy sector of the country. According to the 'The development policy framework' issued by the Sri Lankan government, the country will aim to increasing the share of NCRE power generation to $20 \%$ of total generation by year 2020 [3]. Considering the current phase of developments, experts claim that the said target is a challenge and need considerable effort and commitment from of the authorities.

\section{OUTCOMES OF THE STUDY}

Ten experts representing different disciplines took part in the panel discussion. The panel represented experts in the field of political, economic, environmental and technological aspects of the country. All the experts had a common involvement and interest in the renewable energy sector. Eight key factors, which were later classified into five thematic areas, were derived as the outcome of this study. Table III shows the key factors and their thematic categories.

The workshop was conducted with the aim of identifying the most important factors for the development of renewable energy sector of Sri Lanka. Panel members were also requested to justify, discuss and argue on their selection. Panel members proposed the following arguments to justify the final list.

TABLE III: KEY FACTORS AND THEIR THEMATIC CATEGORIES

\begin{tabular}{|c|c|}
\hline Thematic category & Key Factors \\
\hline $\begin{array}{l}\text { Social aspects of the } \\
\text { country }\end{array}$ & $\begin{array}{l}\text { 01. Energy intensive lifestyle of the public } \\
\text { 02. Education \& public discourse on the } \\
\text { environmental impact. }\end{array}$ \\
\hline $\begin{array}{l}\text { Political vision of } \\
\text { the government }\end{array}$ & $\begin{array}{l}\text { 03. Government policies to strengthen the } \\
\text { renewable energy sector. } \\
\text { 04. Strong private and public sector participation } \\
\text { in the renewable energy sector. }\end{array}$ \\
\hline Economic Factors & $\begin{array}{l}\text { 05. Cost of fossil based thermal energy sources } \\
\text { Vs. cost of renewable energy }\end{array}$ \\
\hline $\begin{array}{l}\text { Environmental } \\
\text { factors }\end{array}$ & $\begin{array}{l}\text { 06. International pressure on emission of } \\
\text { Greenhouse gasses }\end{array}$ \\
\hline $\begin{array}{l}\text { Technological } \\
\text { advancements \& } \\
\text { limitations }\end{array}$ & $\begin{array}{l}\text { 07. Technical limitations in the national grid in } \\
\text { absorbing renewable based electricity. } \\
\text { 08. Global technological advancements in the } \\
\text { renewable energy sector and other associated } \\
\text { industries. }\end{array}$ \\
\hline
\end{tabular}

\section{A. Energy Intensive Lifestyle of the Public}

Though Sri Lanka's energy intensity (MJ/capita/year) is relatively less at present compared to other middle income countries, with increased economic development people's desire to use energy for household needs, industry, services, and agriculture, etc. continuing to grow. Thus, escalating energy demand is an important factor when choosing the renewable energy options for the country.

\section{B. Education and Public Discourse on the Environmental Impact}

In the current context, general public are driven by the economic factors than the environmental factors when meeting their energy requirements. The public awareness and 
disclosure on the adverse environment impact due to fossil fuel use will help to change attitude of general public towards the renewable energy.

\section{Government Policies to Strengthen the Renewable Energy Sector}

Government policies towards the right balance between renewable and non-renewable energy is a crucial factor for the development of renewable energy sector. Incorporation and implementation of such policies will decide the renewable energy future of Sri Lanka.

\section{Strong Private and Public Sector Participation in the Renewable Energy Sector}

Private sector owns all most all the NCRE projects of the country, while the public sector governs the renewable energy sector. Experts claim that, private and public sector participation and interconnection is very much crucial for the development of NCRE sector of Sri Lanka.

\section{E. Cost of Fossil Based Thermal Energy Sources vs. Cost} of Renewable Energy

In the current context renewable energy options are expensive compared to fossil fuels. But for renewable to sustain in long term the prices of renewable energy options should come down.

\section{F. International Pressure on Emission of Greenhouse Gasses}

International agreements such as Kyoto protocol have sets binding obligations on industrialized countries to reduce emissions of GHGs. Market based mechanisms such as Cleaner Development Mechanisms (CDM) will help the country to foster the renewable energy sector.

\section{G. Technical Limitations in the National Grid in Absorbing Renewable Based Electricity}

Unpredictable nature of solar and wind power makes it challenging to integrate them onto the electric grid. The grid, backup power options and energy storage options should be develop overcome such challenges.

\section{H. Global Technological Advancements in the Renewable Energy Sector and Other Associated Industries}

Experts claim that the global technological advancements will make renewable applications affordable, usable, safe and available.

\section{RECOMMENDATIONS}

Sri Lanka is a country blessed with year around sun, wind, rain and lush vegetation and is surrounded by the Indian Ocean. All these natural resources bear testimony to the ample opportunities the country has to harness for energy needs. But we are still lagging behind many other nations in optimizing abundant energy resources.

Irrespective of country's potential today, fossil fuels have dominated the electricity generation and the transportation sector of the country. It is true the Sri Lankan government has the political vision to secure $20 \%$ renewable energy by 2020 , but what is missing is the commitment to hold those responsible for meeting these policy goals. Moreover, Government sends mixed signals of continued subsidization of fossil fuels while encouraging renewables. Poor interconnection between government organizations and the low priority given in the national energy policy for renewable energy sector further evidence this argument. Thus the political commitment is a vital factor that will decide the future of renewable energy sector of Sri Lanka.

Many international studies suggested that strategic cooperation with other nations, industries and private \& public institutions provides an ideal opportunity to enhance sustainable growth by means of developing and sharing resources. The studies claim that most of the renewable energy sources such as hydro, wind, and solar power potentials were under exploited as the resources, technology, knowhow and financing are confined to national boundaries. Such cooperation in the energy sector will help countries to strengthen national energy security, reduce the costs of energy supplies, and minimize adverse impacts from energy price volatility. This will involve a wide range of actions including establishing cross-border infrastructure and promoting international forums for sharing knowledge and experience. Many international organizations battling against the climate change, such as UNFCCC has also identified technology transfer as a cornerstone in developing renewable energy sector in developing countries. Further international financial institutions such as ADB has given due prominence to provide financial assistance for developing countries to provide reliable, adequate, and affordable energy via technology transfer.

\section{CONCLUSION}

Climate Change with the associated increase in global temperature and sea level rise has become the most important global concern in the present day. The current development in the country's economy has resulted in escalating demand for electricity generation. Considering the fact that Sri Lanka's largest reserves of hydro power have already been utilized, country has diversified to thermal power, resulting in a gradual shift in the industry power mix. This study claims that the lack of political commitment, demographic impact and insufficient financial resources are the barriers for the sector's development. Based on the current plan, coal power will be the major share of optimum energy mix and will contribute significantly to the GHG emission. As a small developing nation our contribution is very minimal in terms of global warming and GHG emissions. However this does not diminish our responsibility over the global climate change.

\section{REFERENCES}

[1] United Nations Framework Convention On Climate Change, United Nations, 1992.

[2] A. Kolk and D. van den Buuse, "In search of viable business models for development: sustainable energy in developing countries," Corporate Governance, vol. 12, no. 4, pp. 551-567, 2012.

[3] Sri Lanka Energy Balance 2012: An Analysis of Energy Sector Performance, Sustainable Energy Authority of Sri Lanka, Colombo, 2013.

[4] Sri Lankan Power Sector-Firing the Rain, RAM Ratings Ltd. Colombo, 2012. 
[5] A. Abeygunawardana, "Feed-in-tariff in Sri Lanka," presented at the energy forum, Colombo, 2012.

[6] A. L. E. Streeter and D. de Jongh, "Factors influencing the implementation of clean energy interventions in low-income urban communities in South Africa," Journal of Global Responsibility, vol. 4, no. 1, pp. 76-98, 2013.

[7] D. M. H. S. K. Ranasinghe, "Climate change mitigation-Sri Lanka's perspective," in Proc. International Forestry and Environment Symposium, Colombo, 2012, vol. 15, pp. 290-296.

[8] J. Ratnasiri, "Alternative energy - prospects for Sri Lanka," Journal of the National Science Foundation of Sri Lanka, vol. 36, pp. 89-114, May 2008.

[9] Long Term Generation Expansion Plan, Ceylon Electricity Board, Colombo, 2011.

[10] Long Term Generation Expansion Plan 2013-2032, Ceylon Electricity Board, Colombo, 2013.

[11] Renewable Energy Resource Development Plan, Sustainable Energy Authority of Sri Lanka, Colombo, 2012

[12] M. T. A. P. Wickramarathna, "Economic evaluation of selected pumped storage power plant sites in Sri Lanka," SLEMA Journal, vol. 15 , pp. 6-12, September 2012

[13] Renewables 2012 Global Status Report, Renewable Energy Policy Network for 21st Century (REN21), Paris, 2012.

[14] Renewables 2013 Global Status Report, Renewable Energy Policy Network for 21 st Century (REN21), Paris, 2013.

[15] U. Daranagama, P. Wijayatunga, K. P. Ariyadasa, and W. K. K. Kumarasiri, Feasibility of Dendro Power Based Electricity Generation in Sri Lanka, Intermediate Technology Development Group., Colombo, 1998.

[16] Grid Interconnection Mechanisms for Off-Grid Electricity Schemes in Sri Lanka, Public Utility Commission of Sri Lanka (PUCSL), Colombo, 2013.

[17] M. M. C. Ferdinando and R. J. Gunawardana, "Electricity generation from renewable energy in Sri Lanka: future directions," Ministry of Power and Energy \& Ceylon Electricity Board, Colombo, 2008.

[18] M. Narayana, "Optimum home power systems for off-grid rural electrification in Sri Lanka," Annual Transactions of Institute of Engineers Sri Lanka, pp. 1-6, 2005.

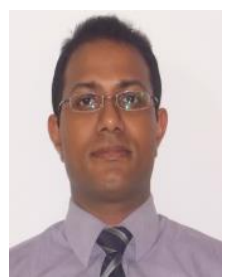

A. S. Withanaarachchi was graduated from the University of Kelaniya in 2006 with B.Sc. (Hon) degree in industrial management. $\mathrm{Mr}$ Withanaarachchi worked as a consultant and has experienced in management capacity in the industry for over 5 years. He obtained masters degree in financial analysis from La Trobe University, Australia in 2010. Presently he is with the Department of Industrial Management, University of Kelaniya. His research interests are in technology transfer \& collaborations, technology foresight and renewable energy technologies.

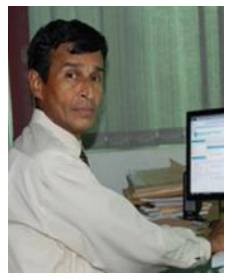

L. D. J. F. Nanayakkara was graduated in the field of mechanical engineering with B.Sc. Eng. (Hon) degree in 1974 from the University of Moratuwa, Sri Lanka. He was qualified with a Ph.D. degree in 1983 in the area of production management and manufacturing technology from the University of Strathclyde, U.K $\mathrm{He}$ had been working as a lecturer, researcher and consultant to industry for over 35 years out of which initial 26 years were in the Department Mechanical Engineering, Faculty of Engineering, University of Moratuwa. Presently, he is a senior lecturer at the Department of Industrial Management, University of Kelaniya. His research interests are in the fields of resource planning and control in ERP systems, modelling, simulation and optimization of production and supply chain operations, and quality management and productivity improvement in business processes.

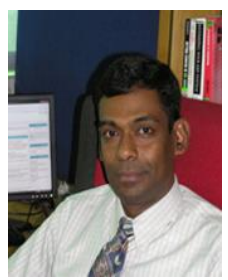

Chamli Pushpakumara was graduated from the University of Kelaniya in 1993 with B.Sc. (Hon) degree in industrial management, and obtained his $\mathrm{PhD}$ in global manufacturing systems at Sheffield Hallam University, UK in 1999. Currently he is serving as the head of the Department of Industrial Management, University of Kelaniya. His research interests are in manufacturing strategy, management of technology. 